\title{
Hipertensão em Situações Especiais
}

\section{Coordenador:}

Carlos E. Poli-de-

Figueiredo (RS)

\section{Secretário:}

Agostinho Tavares (SP)

Participantes:

Elizabete Viana de

Freitas (RJ) - SBGG

Emmanuel de Almeida

Burdmann (SP)

Ivan Luiz Cordovil de

Oliveira (RJ)

Lucélia C. Magalhães

(BA)

Nelson Sass (SP)

Nilzete Liberato

Bresolin (SC) - SBP

Romero Bezerra (DF)

Vera Koch (SP)

Virginia Genelhu

Fagundes (RJ)

\section{Afrodescendentes e Miscigenados}

Os afrodescendentes em geral respondem menos à monoterapia com betabloqueadores, IECA e BRA do que aos diuréticos e ACC dihidropiridínicos (grau de recomendação [GR] II, nível de evidência [EV] B). ${ }^{1,2}$ A escolha do anti-hipertensivo para tratar este grupo étnico é norteada pela presença de comorbidades e pela eficácia em atingir as metas pretendidas. ${ }^{3} \mathrm{O}$ uso de terapia não medicamentosa tem apresentado melhores resultados em afrodescendentes do que em brancos (GRI, EVA). ${ }^{4-6}$ Em indivíduos com proteinúria o uso de IECA está indicado, da mesma forma que ocorre em indivíduos de cor branca (GRI, NEA). ${ }^{7}$

\section{IDosos}

O objetivo do tratamento é a redução gradual da PA para valores abaixo de 140/90 mmHg. Em pacientes com valores muito elevados de PA sistólica, podem ser mantidos inicialmente níveis de até $160 \mathrm{mmHg}$ (GR I, NE A). Não está bem estabelecido o nível mínimo tolerável da PA diastólica (GR I, NE A). ${ }^{8,9}$

$\mathrm{O}$ tratamento não medicamentoso é recomendado para os idosos (GR I, NE A), ${ }^{10}$ e a redução de sal moderada na dieta é benéfica (GR I, NE B). ${ }^{11}$ Quando o tratamento medicamentoso for necessário, a dose inicial deve ser mais baixa, e o incremento de doses ou a associação de novos medicamentos devem ser feitos com mais cuidado (GR I, NE C). A presença de outros fatores de risco e lesões de órgão-alvo e doença cardiovascular associada devem nortear a escolha do anti-hipertensivo inicial (GR I, NE C). ${ }^{12} \mathrm{~A}$ maioria, porém, necessita de terapia combinada, principalmente para o controle adequado da PA sistólica (GR I, NE C).
Ocorre redução de morbidade e mortalidade com diferentes agentes: diuréticos tiazídicos, betabloqueadores em combinação, antagonistas de canais de cálcio de ação longa, IECA e BRA (GR I, $\mathrm{NE}$ A). ${ }^{13-17} \mathrm{O}$ tratamento da hipertensão no idoso reduz a incidência de déficit cognitivo e demência (GR I, NE C). ${ }^{12,18-20}$

$\mathrm{O}$ tratamento de hipertensos com idade acima de 79 anos por meio da associação de IECA e diurético reduziu o desenvolvimento de AVE e das taxas de insuficiência cardíaca (GR IIa, NE B). ${ }^{21}$ As evidências disponíveis sugerem redução de eventos sem impacto sobre a mortalidade (GR IIa, NE B). ${ }^{22}$ Os idosos portadores de comorbidades múltiplas não cardiovasculares devem ter seu tratamento cuidadosamente individualizado.

\section{Crianças e Adolescentes}

Quanto mais altos forem os valores da PA e mais jovem o paciente, maior é a possibilidade de a HAS ser secundária, com maior prevalência das causas renais (GR 1, NE C). A ingestão de álcool, o tabagismo, uso de drogas ilícitas, utilização de hormônios esteroides, hormônio do crescimento, anabolizantes e anticoncepcionais orais devem ser considerados possíveis causas de hipertensão nesta população (GR 1, NE C). O objetivo do tratamento é atingir valores de PA sistólica e diastólica abaixo do percentil 95 para sexo, altura e faixa etária na HAS não complicada, e abaixo do percentil 90 quando complicada por comorbidades. $O$ tratamento não medicamentoso deve ser recomendado a partir do percentil 90 de PA sistólica ou diastólica, correspondente à hipertensão limítrofe (GR 1, NE C). O emprego de medicamentos anti-hipertensivos deve ser 
considerado para os que não respondem ao tratamento não medicamentoso, naqueles com evidência de lesão em órgãos-alvo ou fatores de risco conhecidos, como diabetes, e na hipertensão arterial secundária (GR 1, NE C). Não há estudos de longo prazo sobre o uso de anti-hipertensivos na infância ou na adolescência. A escolha dos medicamentos obedece aos mesmos critérios utilizados para adultos. Medicamentos das classes IECA e BRA II não devem ser utilizados em adolescentes do sexo feminino, exceto quando houver indicação absoluta, em razão da possibilidade de graves efeitos associados à utilização desses medicamentos durante o período gestacional (GR $1, \mathrm{NE} \mathrm{C}) .{ }^{23}$

\section{Hipertensão Arterial na Mulher}

A mulher se expõe a situações especiais que por si só contribuem para o surgimento de HAS - o uso de contraceptivo oral (CO), a gestação e a própria menopausa, como exemplos.

\section{Contraceptivos orais (CO)}

Embora não seja frequente a HAS induzida po CO, os riscos de complicações cardiovasculares associadas ao seu uso são consistentemente maiores em mulheres fumantes, com idade superior a 35 anos. A prescrição de CO deverá levar em conta as seguintes recomendações:

- a menor dose efetiva de estrogênio e progestágeno;

- monitorizar a pressão arterial de seis em seis meses ou a qualquer momento em que a mulher não se sentir bem;

- suspender o uso se a PA se elevar significativamente, provendo outro método anticoncepcional alternativo;

- tratar apropriadamente e proceder à investigação diagnóstica adequada caso a PA não retorne aos valores normais dentro de três meses;

- manter o CO caso não haja outra forma de contracepção aplicável e considerar o uso de anti-hipertensivos para controlar a PA;

- os CO não devem ser utilizados em mulheres fumantes com mais de 35 anos, principalmente se portadoras de HA não controlada, lúpus eritematoso sistêmico, história prévia de doença tromboembólica;

- devem ser usados com cautela em mulheres portadoras de enxaqueca, sendo contraindicados em casos de enxaqueca com aura e sintomas neurológicos focais. ${ }^{24-26}$

\section{HIPERTENSÃO APÓS A MENOPAUSA}

O tratamento da HAS na mulher após a menopausa deve sempre começar por modificações no estilo de vida. Quando necessário são introduzidas drogas anti-hipertensivas. ${ }^{27}$ As decisões de se iniciar o tratamento medicamentoso a partir de valores de PA mais baixos, podem ser tomadas levando-se em conta as mesmas indicações que norteiam o tratamento antihipertensivo nas mulheres em geral.

\section{TERAPÊUTICA DE REPOSIÇÃO HORMONAL (TRH)}

A TRH não é recomendada para prevenção primária ou secundária de doença cardiovascular, podendo mesmo aumentar o risco cardiovascular ou outras doenças, como câncer de mama, demência, tromboembolismo e colecistopatia. Recomenda-se a TRH apenas para o tratamento de sintomas pós-menopáusicos, enfatizando que ela deverá ser prescrita na menor dose efetiva e durante curto período de tempo. ${ }^{28,29} \mathrm{~A}$ simples presença de HAS não deve ser limitação para a TRH se ela tiver que ser aplicada.

\section{HIPERTENSÃO NA GRAVIDEZ}

A definição de hipertensão na gravidez considera os valores absolutos de PA sistólica $>140 \mathrm{mmHg}$ e/ou diastólica $>90 \mathrm{mmHg}$. A PA diastólica deve ser identificada pela fase $\mathrm{V}$ de Korotkoff. ${ }^{30}$ A HAS na gestação é classificada nas seguintes categorias principais: pré-eclâmpsia, eclâmpsia; pré-eclâmpsia superposta à hipertensão crônica; hipertensão crônica; hipertensão gestacional.

\section{PRÉ-ECLÂMPSIA, ECLÂMPSIA E PRÉ-ECLÂMPSIA SOBREPOSTA}

A pré-eclâmpsia é caracterizada pelo aparecimento de HAS e proteinúria (> $300 \mathrm{mg} / 24 \mathrm{~h}$ ) após a $20^{\mathrm{a}}$ semana de gestação em mulheres previamente normotensas. A eclâmpsia corresponde à pré-eclâmpsia complicada por convulsões que não podem ser atribuídas a outras causas. Pré-eclâmpsia superposta à HAS crônica é definida pela elevação aguda da PA à qual se agregam proteinúria, trombocitopenia ou anormalidades da função hepática em gestantes portadoras de HAS crônica, com idade gestacional superior a 20 semanas.

Para prevenção da pré-eclâmpsia não se recomenda prescrever ácido acetilsalicílico para gestantes normais (GR III, NE A), ${ }^{31-33}$ porém em mulheres com risco moderado e elevado de pré-eclâmpsia o uso de baixas doses pode ser útil, sendo iniciado na $12^{\mathrm{a}}$ à $14^{\mathrm{a}}$ semana de gestação (GR IIa, NE B). ${ }^{33-35}$ A suplementação de cálcio não é recomendável para as gestantes que ingerem quantidades normais desse íon (GR III, 
NE A), ${ }^{33}$ mas admite-se que a sua suplementação oral possa ter efeitos favoráveis na prevenção entre gestantes de moderado a alto risco e com baixa ingestão (GR IIa, NE A). ${ }^{36-38}$

$\mathrm{O}$ tratamento definitivo da pré-eclâmpsia é a interrupção da gestação, sempre benéfica para a mãe. Entretanto, a interrupção da gestação pode não ser benéfica para o feto devido às complicações inerentes à prematuridade. Embora o feto esteja também em risco, muitas vezes é instituído tratamento conservador para assegurar maior grau de maturidade fetal..$^{30}$

O tempo para a interrupção da gravidez é baseado, sobretudo na idade gestacional, nas condições maternas e fetais e na gravidade da pré-eclâmpsia. $\mathrm{Na}$ gestação a termo não existem dúvidas e a indicação é feita no momento do diagnóstico. Recomenda-se, ainda, que a intervenção seja considerada em todos os casos a partir da 37 a semana de gravidez (GR IIa, NE C). ${ }^{39-41}$ No período pré-termo, inferior a 37 semanas, algumas considerações deverão ser feitas:

- mulheres com idade gestacional de 32 a 34 semanas e mais poderão ser consideradas para tratamento conservador em unidades especializadas (GR IIa, NE C);

- a administração de corticoide está indicada para grávidas pré-eclâmpticas com idade gestacional entre 24 e 34 semanas (GR IIa, NE B); ${ }^{42}$

- a interrupção da gestação deverá sempre ser considerada nos casos de pré-eclâmpsia grave independentemente da idade gestacional. ${ }^{41}$

Recomenda-se o uso de sulfato de magnésio para prevenir eclâmpsia em mulheres com pré-eclâmpsia grave (GR I, NE A) e para a prevenção de eclâmpsia, se a pré-eclâmpsia é leve, porém com impacto diferente (GR IIa, NE B). ${ }^{43}$

As indicações para o tratamento anti-hipertensivo não se baseiam em ensaios clínicos com desfechos claramente definidos, mas sim em padrões da prática clínica estabelecidos ao longo de muitos anos.

Sugere-se que o tratamento seja instituído mais precocemente quando a PA for $\geq 150 / 100 \mathrm{mmHg} .{ }^{44}$ Em situações especiais, como é o caso de gestantes adolescentes com PA anterior à gravidez inferior a 90/75 mmHg e em grávidas com sintomas que podem ser atribuídos à HAS, admite-se iniciar o tratamento mais precocemente..$^{30} \mathrm{O}$ objetivo do tratamento anti-hipertensivo na pré-eclâmpsia é alcançar PA sistólica entre 130 a $150 \mathrm{mmHg}$ e PA diastólica de 80 a 100 mmHg. ${ }^{44}$

Quanto ao tratamento, dois cenários devem ser considerados:
- Tratamento agudo - Em urgência ou emergência hipertensiva requerendo hospitalização, monitoração intensiva, antecipação do parto e administração parenteral de anti-hipertensivos; recomenda-se a administração endovenosa de sulfato de magnésio considerado a droga de escolha para prevenção da eclâmpsia (GR I, NE A). ${ }^{41}$ Para o tratamento da HAS grave recomenda-se hidralazina endovenosa. ${ }^{30}$ A escolha para o tratamento da emergência hipertensiva dependerá da experiência e familiaridade com a medicação. Em situações excepcionais, principalmente quando existe risco de edema pulmonar concomitante, admite-se o uso de nitroprussiato de sódio por período inferior a quatro horas, como última opção para controle urgente da HAS grave e refratária. ${ }^{30,45}$

A administração de nifedipino de ação rápida, por via oral ou sublingual, deve ser evitada (GR III). ${ }^{46}$

- Tratamento de longo prazo - Em pacientes com pré-eclâmpsia com quadro clínico estabilizado sem necessidade de parto imediato, está indicado tratamento anti-hipertensivo por via oral (GRI, NE B). ${ }^{44}$ Recomenda-se não prescrever anti-hipertensivo para HAS com valores de $\mathrm{PA}<150 / 100 \mathrm{mmHg}$ associada a pré-eclâmpsia (GR II, NE B $)^{45}$ ou a hipertensão crônica (GR II, NE B). ${ }^{44}$ Não há comprovação de benefícios para a mãe ou para o feto, exceto redução do risco de HAS grave, que é considerado insuficiente diante da exposição do feto ao risco potencial de comprometimento do seu crescimento. ${ }^{47}$

As opções de uso de anti-hipertensivos orais são as mesmas apresentadas para as gestantes portadoras de HA crônica ou preexistente. A alfametildopa é a droga preferida por ser a mais bem estudada e não haver evidência de efeitos deletérios para o feto (GR I, NE C). ${ }^{30}$ Outros ACC, como nifedipino, anlodipino e verapamil, podem ser considerados drogas alternativas. ${ }^{44,48,49}$ Os betabloqueadores são considerados seguros na gravidez, embora se atribua a eles redução no crescimento fetal. ${ }^{50}$

$\mathrm{Na}$ pré-eclâmpsia, a prescrição de diuréticos é geralmente evitada, porém os tiazídicos podem ser continuados em gestantes com HA crônica, desde que não promovam depleção de volume..$^{51,52}$ Os IECAs e os BRAs são contraindicados. . $33,54^{-5}$ 


\section{HIPERTENSÃO ARTERIAL SISTÊMICACRÔNICA}

A HAS crônica é definida por hipertensão registrada antes da gestação, no período que precede a $20^{\underline{a}}$ semana de gravidez, ou além de doze semanas após o parto.

Em relação à HAS crônica, recomenda-se o início ou a reinstituição do tratamento medicamentoso com PA sistólica $\geq 150 \mathrm{mmHg}$ e PA diastólica de 95 a $99 \mathrm{mmHg}$ ou sinais de lesão em órgão-alvo. ${ }^{44}$ Para gestantes portadoras de HAS crônica que estão em uso de anti-hipertensivos e PA $<120 / 80 \mathrm{mmHg}$, recomenda-se reduzir ou mesmo descontinuar o tratamento e iniciar monitorização cuidadosa da PA (GR II, NE C). ${ }^{44}$

\section{HIPERTENSÃO GESTACIONAL}

É caracterizada por HA detectada após a 20ª semana, sem proteinúria, podendo ser definida como "transitória” quando ocorre normalização após o parto ou "crônica" quando persistir a hipertensão.

\section{Tratamento Anti-hipertensivo na Lactante}

A utilização de anti-hipertensivos na mulher que está amamentando merece alguns cuidados. É necessário considerar que todos os medicamentos, de alguma forma e com diferentes concentrações, passam para o leite materno. A Tabela 1 mostra as medicações anti-hipertensivas disponíveis no Brasil consideradas seguras, moderadamente seguras e as não recomendadas para essa situação em particular. ${ }^{55}$

\section{Tabela 1 SEgurANÇA PARA O LACTENTE COM O USO DE MEDICAÇÕES ANTI-HIPERTENSIVAS PELA LACTANTE ${ }^{55}$}

\section{Medicamentos}

Diuréticos: hidroclorotiazida, espironolactona

Inibidores adrenérgicos: alfametildopa, propranolol

Vasodilatadores: hidralazina, minoxidil

Antagonistas dos canais de cálcio: verapamil, nifedipino, nitrendipino

Inibidores da ECA: benazapril, captopril, enalapril, quinadril

in

Inibidores adrenérgicos: atenolol, bisoprolol, carvedilol, metoprolol

Antagonistas dos canais de cálcio: anlodipino, isradipino, nisoldipino

Inibidores da ECA: fosinopril, lisinopril, ramipril

Bloqueadores do receptor $\mathrm{AT}_{1}$ : candesartana, olmesartana, telmisartana

Inibidores adrenérgicos: reserpina, nadolol, prazosina, terazosina

Inibidores da ECA: fosinopril*, quinapril*

Bloqueadores do receptor $\mathrm{AT}_{1}$ : telmisartana*, valsartana

Recomendação

* uso no período perinatal.

\section{REFERÊNCIAS}

1. Park IU, Taylor AL. Race and ethnicity in trials of antihypertensive therapy to prevent cardiovascular outcomes: a systematic review. Ann Fam Med 2007; 5:444-452.

2. Freis ED, Reda DJ, Materson BJ. Volume (weight) loss and blood pressure response following thiazide duiretics. Hypertension 1988; 12:244-250.

3. Brewster LM, van Montfrans GA, Kleijnen J. Systematic review: antihypertensive drug therapy in black patients. Ann Intern Med 2004; 141:614-627.

4. MacGregor GA, Markandu ND, Best FI et al. Doubleblind randomized crossover trial of moderate sodium restriction in essential hypertension. Lancet 1982; 351-355.

5. Shaper AG, Leonard PJ, Jones KW, Jones M. Environmental effects on the body built, blood pressure and blood chemistry of nomadic warriors serving in the army of Kenya. East Afric Med J 1969; 46:282-289.
6. Luft FC, Rankin LI, Bloch R et al. Cardiovascular and humoral responses to extremes of sodium intake in normal black and white men. Circulation 1979; 60:697-706.

7. Wright JT, Bakris G, Greene T et al, for the African American Study of Kidney Disease and Hypertension Study Group. Effect of blood pressure lowering and antihypertensive drug class on progression of hypertensive kidney disease. Results from the AASK Trial. JAMA 2002; 288:2421-2431.

8. Somes GW, Pahor M, Shorr RI, Cushman WC, Applegate WB. The role of diastolic blood pressure when treating isolated systolic hypertension. Arch Int Med 1999; 159:2004-2009.

9. Messerli FH, Panjrath GS. The J-Curve betweenblood pressure and coronary artery disease or essential hypertension. Exactly how essential? J Am Coll Cardiol 2009; 54:1827-1834.

10. Whelton PK, Appel LJ, Espeland MA et al. Sodium reduction and weight loss in the treatment of hypertension in older people: a randomized controlled trial of 
nonpharmacologic interventions in the elderly (TONE). TONE Collaborative Research Group. JAMA 1998; 279:839-846.

11. Appel LJ, Espeland MA, Easter L, Wilson AC, Folmar S, Clifton R. Effects of reduced sodium intake on hypertension control in older individuals: results from the Trial of Nonpharmacologic Interventions in the Elderly (TONE). Arch Intern Med 2001; 161:685-693.

12. Mancia G, De Backer G, Dominiczak A et al. The task force for the management of arterial hypertension of the European Society of Hypertension, The task force for the management of arterial hypertension of the European Society of Cardiology. 2007 Guidelines for the management of arterial hypertension: The task force for the management of arterial hypertension of the European Society of Hypertension (ESH) and of the European Society of Cardiology. Eur Heart J 2007; 28:1462-1536.

13. SHEP Cooperative Research Group. Prevention of stroke by antihypertensive drug treatment in older persons with isolated systolic hypertension. Final results of the Systolic Hypertension in the Elderly Program (SHEP). JAMA 1991; 265:3255-3264.

14. Staessen JA, Fagard R, Thijs L et al. Randomized double-blind comparison of placebo and active treatment for older patients with isolated systolic hypertension. The Systolic Hypertension in Europe (SYST-EUR) Trial Investigators. Lancet 1997; 350:757-764.

15. Hansson L, Lindholm LH, Ekbom $\mathrm{T}$ et al., for the STOP-Hypertension-2 study group. Randomised trial of old and new antihypertensive drugs in elderly patients: cardiovascular mortality and morbidity the Swedish Trial in Old Patients with Hypertension-2 study. Lancet, 1999; 354:1751-1756.

16. The ALLHAT Officers and Coordinators for the ALLHAT Collaborative Research Group. Major outcomes in high-risk hypertensive patients randomized to angiotensin-converting enzyme inhibitor or calcium channel blocker $v$ s. diuretic: The Antihypertensive and Lipid-Lowering treatment to prevent Heart Attack Trial (ALLHAT). JAMA 2002; 288:2981-2997.

17. Lithell H, Hansson L, Skogg I et al., for the SCOPE Study Group. The Study on Cognition and Progno-sis in the Elderly (SCOPE): principal results of a randomized double-blind intervention trial. J Hypertens 2003; 21:875-886.

18. Forette F, Seux ML, Staessen JA et al., for the Systolic Hypertension in Europe Investigators. The prevention of dementia with antihypertensive treatment. New evidence from the Systolic Hypertension in Europe (Syst-Eur) study. Arch Intern Med 2002; 162(18):2046-2052.

19. The PROGRESS Collaborative Group. Effects of blood pressure lowering with perindopril and indapamide therapy on dementia and cognitive decline in patients with cerebrovascular disease. Arch Intern Med 2003; 163:1069-1075.

20. Papademitriou V, Farsang C, Elmfeldt D et al., for the SCOPE Study Group. Stroke prevention with the angiotensin II type 1 receptor blocker candesartan in elderly patients with isolated systolic hypertension. The study on cognition and prognosis in the elderly (SCOPE). J Am Coll Cardiol 2004; 44:1175-1180.
21. Becket NS, Peters R, Fletcher AE et al. The HYVET Study Group. The HYVET Study Group Treatment of Hypertension in patients 80 years of age and older. $\mathrm{N}$ Engl J 2008; 358:1887-1898.

22. Gueyffier F, Bulpitt C, Boissel JP et al, for the INDIANA Group. Antihypertensive drugs in very old people: a sub-group analysis of randomised controlled trials. Lancet 1999; 353:793-796.

23. National High Blood Pressure Education Program Working Group on High Blood Pressure in Children and Adolescents. The fourth report on the diagnosis, evaluation, and treatment of high blood pressure in children and adolescents. Pediatrics 2004; 114:555-576.

24. Croft P, Hannaford PC. Risk factors for acute myocardial infarction in women: evidence from the Royal College of General Practitioners Oral Contraception Study. BMJ 1989; 298:165-168.

25. Woods JW. Oral contraceptives and hypertension. Hypertension 1988; 11 (suppl II):II-11-II-15.

26. Chasan-Taber L, Willett WC, Manson JE et al. Prospective study of oral contraceptives and hypertension among women in the United States. Circulation 1996; 94:483-489.

27. Stampfer MJ, Hu FB, Manson JE, Rimm EB, Willet WC. Primary prevention of coronary heart disease in women through diet and lifestyle. N Engl J Med 2000; 343:16-22.

28. Hulley S, Grady D, Bush T, et al., for the Heart and Estrogen/progestin Replacement Study (HERS) Research Group. Randomized trial of estrogen plus progestin for secondary prevention of coronary heart disease in postmenopausal women. JAMA 1998; 280:605.

29. Writing Group for the Women's Health Initiative Investigators. Risk and benefits of estrogen plus progestin in health post-menopausal women. Principal results from the Women's Health Initiative randomized controlled trial. JAMA 2002; 288:321-333.

30. National High Blood Pressure Education Program Working Group on High Blood Pressure in Pregnancy. Report of the National High Blood Pressure Education Program Working Group on High Blood Pressure in Pregnancy. Am J Obstet Gynecol 2000; 183:S1-S22.

31. CLASP: a randomised trial of low-dose aspirin for the prevention and treatment of pre-eclampsia among 9364 pregnant women. CLASP (Collaborative Lowdose Aspirin Study in Pregnancy) Collaborative Group. Lancet 1994; 343:619-629.

32. Caritis S, Sibai B, Hauth J et al. Low-dose aspirin to prevent preeclampsia in women at high risk. N Engl J Med 1998; 338:701-705.

33. August P. Prevention of preeclampsia. Up ToDate Version 17.3:sep 2009 [acesso em 12 Jan 2010]. Disponível em http://www. uptodate.com.

34. Coomarasamy A, Honest H, Papaioannou S, Gee H, Khan KS. Aspirin for prevention of preeclampsia in women with historical risk factors: a systematic review. Obstet Gynecol 2003; 101:1319-1332.

35. Askie LM, Duley L, Henderson-Smart D, Stewart LA, on behalf of the PARIS Collaborative Group. Antiplatelet agents for prevention of pre-eclampsia: a meta-analysis of individual patient data. Lancet 2007; 369:1791-1798. 
36. Hofmeyr GJ, Atallah NA, Duley L. Calcium supplementation during pregnancy for preventing hypertensive disorders and related problems, Cochrane Database of Systematic Reviews. In: The Cochrane Library, Issue 3, Art. No. CD001059. DOI:10.1002/14651858. CD001059.pub3.

37. Bucher HC, Guyatt GH, Cook RJ et al. Effect of calcium supplementation on pregnancy-induced hypertension and preeclampsia. A meta-analysis of randomized controlled trials. JAMA 1996; 275:1113-1117.

38. DerSimonian R, Levine RJ. Resolving discrepancies between a meta-analysis and a subsequent large controlled trial. JAMA 1999; 282:664-670.

39. Churchill D, Duley L. Interventionist versus expectant care for severe pre-eclampsia before term. Cochrane Database of Systematic Reviews. In: The Cochrane Library, Issue 3, Art. No. CD003106. DOI:10.1002/14651858.CD003106.pub3.

40. Duley L, Henderson-Smart DJ, Meher S. Drugs for treatment of very high blood pressure during pregnancy. Cochrane Database of Systematic Reviews. In: The Cochrane Library, 2009, Issue 3, Art. No. CD001449. DOI:10.1002/14651858.CD001449.pub2.

41. Norwitz ER, Repke JT. Management of preeclampsia. UpToDate Version 17.3:Sep 2009 [acesso em 12 Jan 2010]. Disponível em http://www.uptodate.com.

42. Devender R, Dalziel SR. Antenatal corticosteroids for accelerating fetal lung maturation for women at risk of preterm birth. Cochrane Database of Systematic Reviews. In: The Cochrane Library, Issue 3, Art. No. CD004454. DOI:10.1002/14651858.CD004454.pub3.

43. Duley L, Gülmezoglu AM, Henderson-Smart DJ. Magnesium sulphate and other anticonvulsants for women with pre-eclampsia. Cochrane Database of Systematic Reviews. In: The Cochrane Library, Issue 3, Art. No. CD000025. DOI:10.1002/14651858.CD000025.pub3.

44. August P. Management of hypertension in pregnancy. UpToDate Version 17.3:Sep 2009 [acesso em 12 Jan 2010]. Disponível em http://www.uptodate.com.
45. Sass N, Itamoto CH, Silva M P, Torloni MR, Atallah AN. Does sodium nitroprusside kill babies? A systematic review. Sao Paulo Med J 2007; 125:108-111.

46. Impey, L. Severe hypotension and fetal distress following sublingual administration of nifedipine to a patient with severe pregnancy induced hypertension at 33 weeks. Br J Obstet Gynaecol 1993; 100:959.

47. Abalos E, Duley L, Steyn DW, Henderson-Smart DJ. Antihypertensive drug therapy for mild to moderate hypertension during pregnancy. Cochrane Database of Systematic Reviews. In: The Cochrane Library, Issue 3, Art. No. CD002252. DOI:10.1002/14651858. CD002252.pub2.

48. Magee LA, Schick B, Donnenfeld AE et al. The safety of calcium channel blockers in human pregnancy: a prospective multicenter cohort study. Am J Obstet Gynecol 1996; 174:823-828.

49. Podymow T, August P, Umans JG. Antihypertensive therapy in pregnancy. Semin Nephrol 2004; 24:616-625.

50. Butters L, Kennedy S, Rubin PC. Atenolol in essential hypertension during pregnancy. BMJ 1990; 301:587-589.

51. Cunningham FG, Lindheimer MD. Hypertension in pregnancy. N Engl J Med 1992; 326:927-932.

52. Sibai BM, Grossman RA, Grossman HG. Effects of diuretics on plasma volume in pregnancies with long-term hypertension. Am J Obstet Gynecol 1984; 150:831-835.

53. Shotan A, Widerhorn J, Hurst A, Elkayam U. Risks of angiotensin-converting enzyme inhibition during pregnancy: experimental and clinical evidence, potential mechanisms, and recommendations for use. Am J Med 1994; 96:451-456.

54. Saji H, Yamanaka M, Hagiwara A, Ijiri R. Losartan and fetal toxic effects. Lancet 2001; 357:363.

55. Chaves RG, Lamounier JA, César CC. Medicamentos e amamentação: atualização e revisão aplicadas à clínica materno-infantil. Rev Paul Pediatr 2007; 25:276-288. 